\title{
PRELIMINARY RESULTS OF THE MAPPING OF THE TERTIARY BASALTS IN WESTERN NUGGSSUAQ
}

\author{
Niels Hald
}

\section{Introduction}

The purpose of the investigations during the summer of 1971 was partly to map the Nûgssuaq peninsula west of the Itivdle valley and partly to continue the collecting of rocks for a petrological description of the upper lava formation on Nûgssuaq and Hareøen (Hald, 1971).

\section{Regional geology}

Precambrian metamorphic rocks are present in the eastern part of Nûgssuaq. They are overlain by marine and limnic sediments from the Cretaceous and Lower Tertiary (Danian). These sediments are overlain by Tertiary lavas and pyroclastic rocks of mainly basaltic composition. The igneous rocks comprise a lower formation characterized by palagonite breccias and lavas rich in olivine and an upper formation characterized by tholeiitic lavas with phenocrysts of plagioclase. (A summary of the geology of the district is found in Rosenkrantz \& Pulvertaft, 1969.)

Nûgssuaq is traversed by several large fault systems. The Itivdle valley, which limits the area investigated towards the east, is eroded in one of those systems. The area west of Itivdle is faulted down, but the displacement is not known.

The dips in the lavas and sediments in the area west of Itivdle are generally towards the north-west. The oldest rocks in the area - sediments from the Cretaceous and the Danian - are found at the coast nearest to the Itivdle valley. To the west of the sediments and separated from them by faults are basalts belonging to the lower lava formation, which like the sediments only appear in small areas. The lavas forming the rest of the area belong to the upper lava formation. Partly because of a proposal by Henderson (1969) this unit in western Nûgssuaq has been divided into a lower member with thin flows and an upper member with thicker flows. (The stratigraphic nomenclature used in this account is informal.) 
The surface of the western part of Nûgssuaq is comparatively plane. Nearest to Itivdle there is a plateau at a height of $700-1000 \mathrm{~m}$ whereas the surface further west slopes towards the north-west coast. The best exposures are found in the cliffs at the north and south coasts and at the western side of the deeply eroded Itivdle valley. Good exposures are also found in the largest valleys, especially Kûp qôrorssua, Itsatagdlip qôrua and Naquerdloq.

\section{Previous investigations}

The earliest geological investigations of western Nûgssuaq concerned small occurrences of coal-bearing interbasaltic sediments (see, for example, Nordenskiöld, 1871; Steenstrup, 1883). The stratigraphy of the Tertiary basalts and the tectonic development of the western part of Nûgssuaq have been investigated by Munck \& Noe-Nygaard (1957), Münther (1973) and Henderson (1969, in press). Henderson has compiled a geological map at scale 1:100 000 (to be published as 70 V. $1 \mathrm{~N}$, Agatdal) covering the greater part of Nûgssuaq. The mapping of 1971 has been based upon this map.

\section{Lower lava formation}

Olivine basalts belonging to the lower lava formation are known from the area round Manîdlat and Sangmissoq at the north coast and around Nûlûp qáqai and Sermersalik at the south coast (see fig. 3). The olivine basalts are separated by faults from the older sediments as well as from the younger lavas. They are themselves cut by many faults with large displacements. It has not yet been possible to make a correlation between the faulted blocks, and their stratigraphic position in relation to the lavas of the lower lava formation east of Itivdle is not known.

The basalts appear typically as $1-3 \mathrm{~m}$ thick pahoehoe lavas consisting of aphyric or olivine-porphyritic, very fine-grained, vesicular olivine basalts. The lavas often contain residual veins up to $10 \mathrm{~cm}$ wide consisting of a more coarsegrained, strongly vesicular olivine basalt. 5 to $10 \mathrm{~m}$ thick flows of only slightly vesicular, olivine-porphyritic or aphyric olivine basalt are found but are less common.

\section{Upper lava formation}

\section{Lower member}

The lower member is separated by faults from the olivine basalts of the lower lava formation. The upper boundary is exposed on the north coast where the 

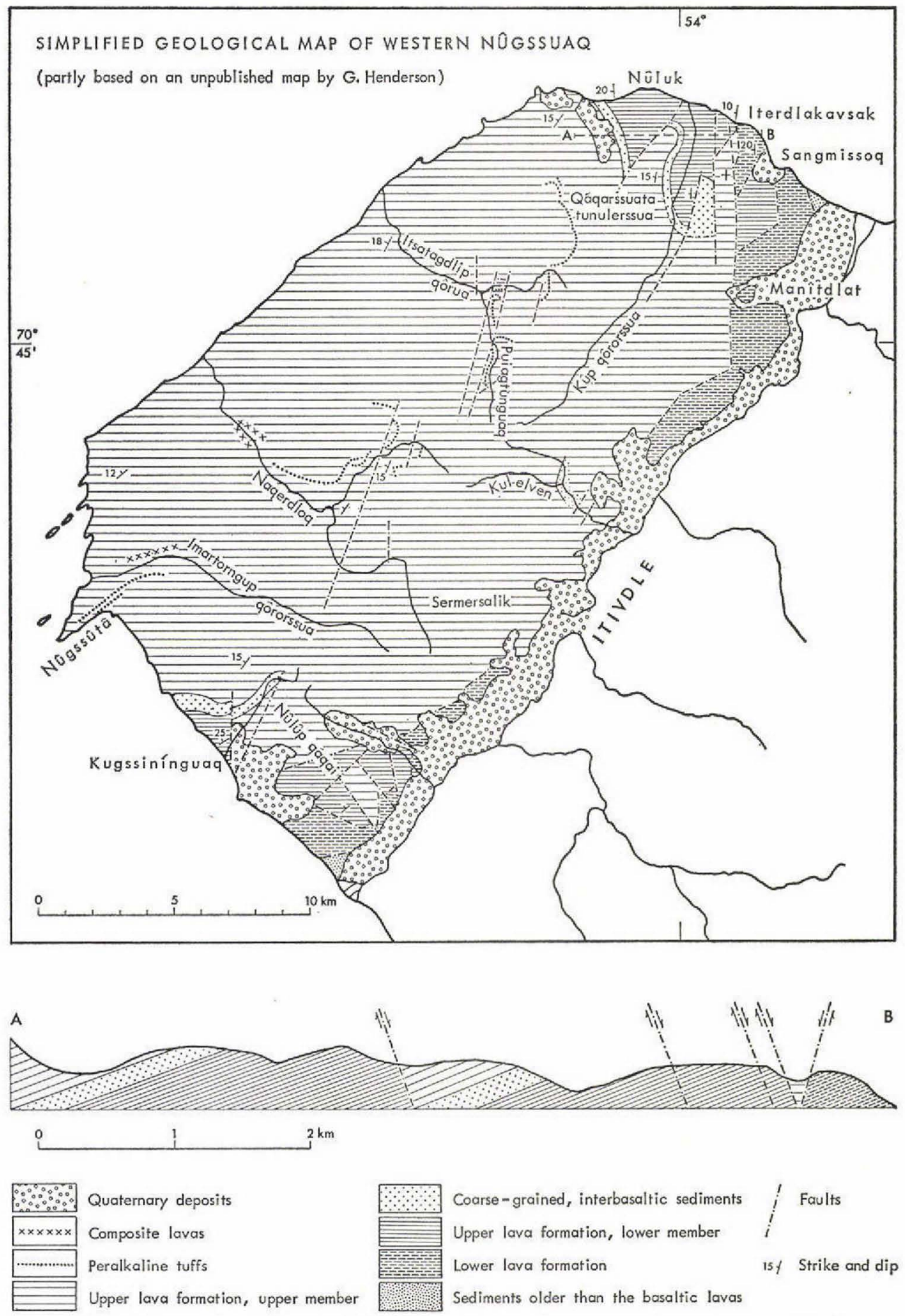

$\begin{array}{ll}\text { Coarse-grained, interbasaltic sediments } & i \text { Faults } \\ \text { Upper lava formation, lower member } & i \\ \text { Lower lava formation } & \text { 15y Strike and dip }\end{array}$

Sediments older than the basaltic lavas

Fig. 3. Simplified geological map of western Nûgssuaq (partly based on an unpublished map by $\mathrm{G}$. Henderson). Note that map and section are on different scales, and that the dips shown on the section are only approximate. 


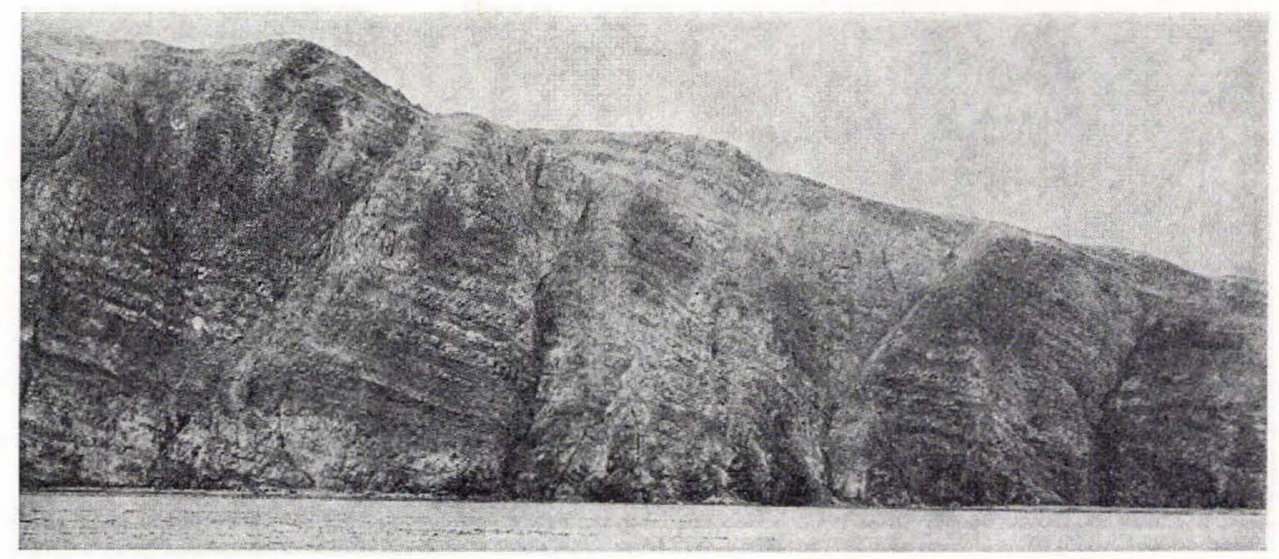

Fig. 4. Thin plagioclase-porphyritic lavas from the lower member of the upper lava formation. The height of the profile is about $300 \mathrm{~m}$. North coast of Nûgssuaq east of Kûp qôrorssua.

lavas underlie sediments at Nûluk and Kûp qôrorssua. Basalts in the area between Sangmissoq and Manîdlat belong presumably to the same member. At Nûlûp qáqai and Kugssinínguaq on the south coast are basalts which may also be referred to this member.

The member is characterized partly by the relative thinness of the lava flows (generally $5-10 \mathrm{~m}$, but flows up to $15 \mathrm{~m}$ thick occur), and partly by the fact that pahoehoe lavas make up a considerable part of the member (see fig. 4). On the north coast there are at several levels flow groups up to $50 \mathrm{~m}$ thick consisting of flows of aphyric lava, $1 / 2-2 \mathrm{~m}$ thick, with strongly vesicular top and bottom layers. In the lower part of the member there are a few olivine basalts of the same type as those in the lower lava formation. The tholeiitic lavas are fine grained with doleritic texture. They contain phenocrysts of plagioclase with bytownitic cores and augite. The olivine is nearly always replaced by secondary minerals.

Near the top of Nûlûp qáqai there is a light-coloured contaminated basalt with xenoliths of sandstone. The phenocrysts consist of strongly corroded plagioclase and of augite. It may be noted that a sequence of sediment-contaminated basalts about $200 \mathrm{~m}$ thick has been described by Pedersen (1970) from the lower part of the upper lava formation in the western part of Disko.

A light-coloured, feldspar-porphyritic ignimbritic tuff about $20 \mathrm{~m}$ thick was found by Henderson (pers. comm.) in the valley between Nûlûp qáqai and Sermersalik. Other ignimbrites are known from the western part of Nûlûp qáqai and from the mouth of Kugssinínguaq. 


\section{Interbasaltic sediments}

On the north coast of Nûgssuaq (at Kûp qôrorssua and Nûluk) as well as on the south coast (at Kugssininguaq) and in Kulelven there are coarse-grained sediments more than $100 \mathrm{~m}$ thick. The sediments are greyish brown or yellow brown and consist of angular fragments of a generally aphyric basalt in a fine-grained matrix. Other rock fragments (coal, clay-ironstone, siliceous sinter) are rare. The fragments are typically $1-5 \mathrm{~cm}$, but blocks up to $1 / 2 \mathrm{~m}$ across occur (see fig. 5).

The sediment is layered with some sorting of the fragments according to size. At a few places there are thin sandstone layers in which plant remains can be found. Sometimes the sediment has a tuffaceous character with many fragments of black volcanic glass.

The coarse-grained sediments are generally overlain by layers of feldspar-porphyritic tuffs, sandstone, clay-ironstone and coal. These layers have been mentioned by Steenstrup (1883), Koch (1964) and others.

On the north coast the coarse-grained sediments overlie discordantly the lower, thinly bedded member. At Kugssinínguaq only a limited section of the underlying

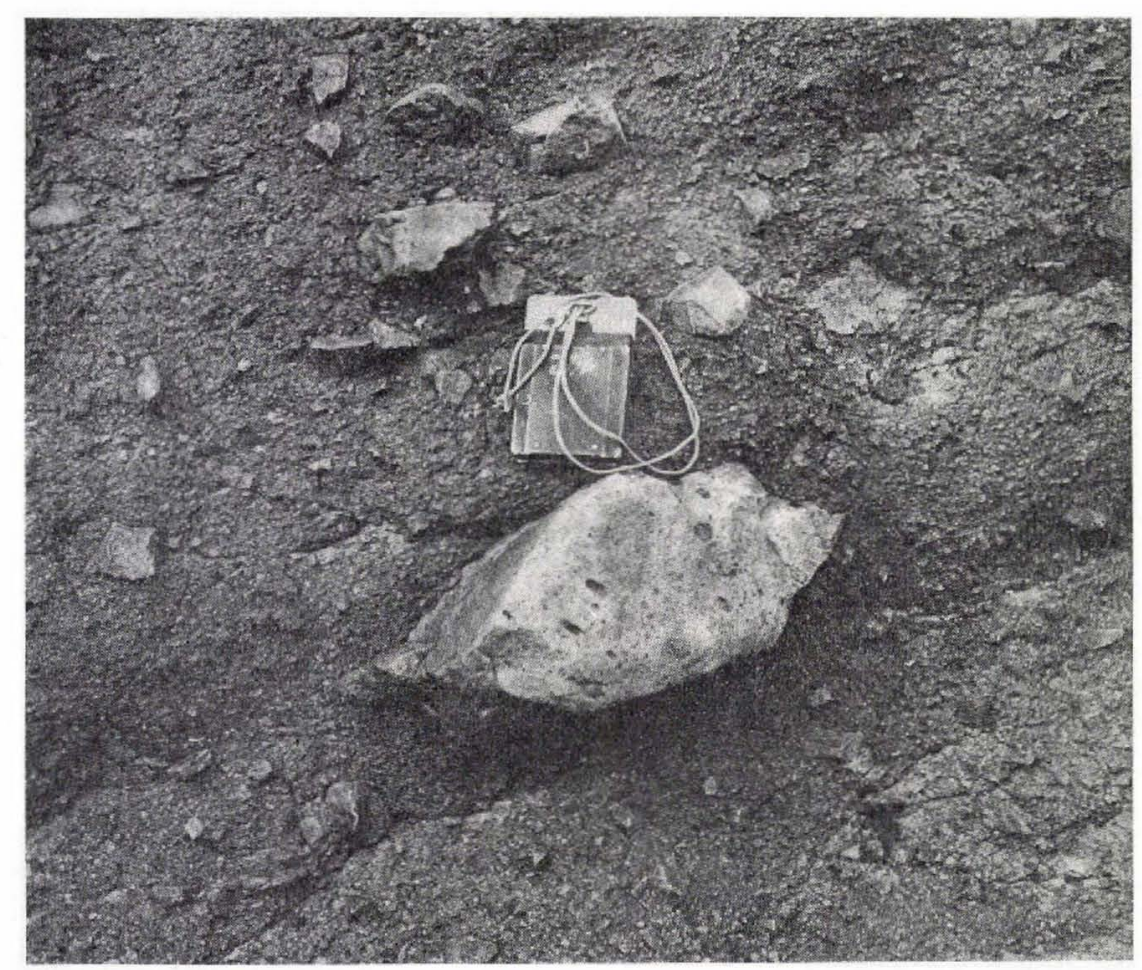

Fig. 5. Coarse-grained interbasaltic sediments. Kûp qôrorssua, north coast of Nûgssuaq. 


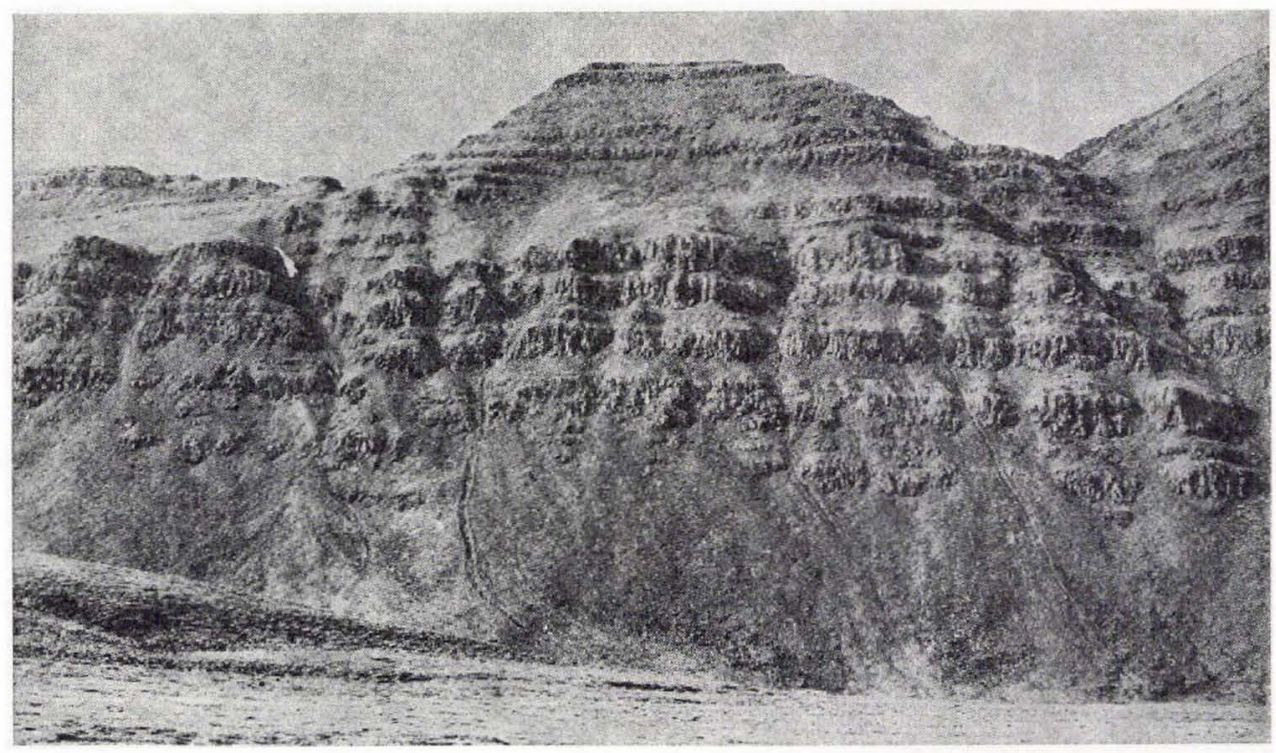

Fig. 6. Thick plagioclase-porphyritic lavas from the upper member of the upper lava formation. The height of the profile is about $300 \mathrm{~m}$. North coast of Nûgssuaq west of Nûluk.

basalts is exposed, but these show a morphological resemblance to the lower zone on the north coast. At Kulelven directly underlying basalts are not exposed.

In the area west of Itivdle coarse-grained sediments are only found at a few places and always as much thinner layers. Furthermore, the sediments at Kugssinínguaq and Kulelven are overlain by basalts typical of the lower part of the upper member as developed on the north coast of Nûgssuaq (cf. below). Accordingly it will be presumed that the sediments at the three localities belong to the same level.

\section{Upper member}

The coarse-grained sediments are overlain by $15-20 \mathrm{~m}$ thick tholeiitic lavas. The flows are slightly vesicular and the upper $2-4 \mathrm{~m}$ of each flow is scoriaceous (see fig. 6).

In the member as a whole aa lavas, $10-15 \mathrm{~m}$ thick, are predominant, but there are locally small sequences of $5 \mathrm{~m}$ thick pahoehoe lavas, e.g. at the mouth of Itsatagdlip qôrna.

The flows consist of fine-grained, tholeiitic basalt with doleritic texture. In the lower part of the member the basalt is porphyritic with phenocrysts of olivine, plagioclase with bytownitic cores and augite. Higher in the member basalts which are either aphyric or with microphenocrysts of plagioclase, augite and olivine are predominant. 
Preliminary chemical analyses show that the lavas of the lower member contain 0.1-0.2 per cent $\mathrm{K}_{2} \mathrm{O}$ whereas the lavas just above the coarse-grained sediments contain $0.8-1.0$ per cent $\mathrm{K}_{2} \mathrm{O}$. The uppermost aphyric or microporphyritic lavas contain $0.4-0.6$ per cent $\mathrm{K}_{2} \mathrm{O}$.

\section{Tuffs}

The thickly bedded member is very monotonously developed, and it has not been possible to find basalt flows or groups of flows which can be used as marker horizons. On the other hand thin tuff layers occur at several places: in the area west of Qáqarssuata tunulerssua; in the inner part of Itsatagdlip qôrua; in the inner part of Naqerdloq; and on Nûgssûtâ at the south coast of Nûgssuaq.

During the field work à distinction was made between light, slightly reddish or grey tuffs and darker greyish green tuffs. The light tuffs are fine grained. Rock fragments and crystal fragments are rarely more than $1 \mathrm{~mm}$ across. The phenocrysts are typically alkali feldspar and pyroxene. The tuffs can be welded.

The greenish tuffs can also be very fine grained, but at several places in the south-western part of the mapped area the rock fragments can be more than $1 \mathrm{~cm}$ across. The phenocrysts are typically alkali feldspar and aenigmatite but a green pyroxene is also common. An isotropic brown mineral (presumably garnet) appears in the tuffs of the northern side of Naqerdloq. The greeenish tuffs can also be welded.

Whereas the aenigmatite-bearing tuffs are known from all the above-mentioned districts the light tuffs are only known from the three northern districts.

The tuff layers in the four areas are stratigraphically near the level at which plagioclase-porphyritic basalts are succeeded by aphyric basalt, a level which is not necessarily a chronostratigraphic level.

The tuffs west of Qáqarssuata tunulerssua and the tuffs on Nûgssûtâ are estimated to lie $1000 \mathrm{~m}$ stratigraphically above the coarse-grained, interbasaltic sediments. Furthermore, the tuffs of Nûgssûtâ and at Naqerdloq both lie about $300 \mathrm{~m}$ stratigraphically below a composite lava mentioned below.

It will therefore be assumed that the tuff layers are situated at approximately the same level.

\section{Composite lava}

A $15 \mathrm{~m}$ thick composite lava can be traced for two kilometres along the north side of Imartorngup qôrorssua. The lower part of the lava consists of a dark grey, aphyric very fine-grained, basaltic rock, whereas the upper part consists of a light grey, acid rock, with phenocrysts of plagioclase and ore. Overlying this composite lava there is a black acid glass with phenocrysts of plagioclase, augite and ore.

The composite lava with overlying black glass was also found on both sides of Naqerdloq valley. 


\section{Dykes}

The dykes on western Nûgssuaq fall petrographically into three groups: dykes consisting of olivine basalt with phenocrysts of olivine in a very fine-grained matrix; dykes consisting of tholeiitic basalt with phenocrysts of plagioclase and commonly also of augite and partially replaced olivine in a very fine-grained matrix; dykes consiting of slightly alkaline, fine-grained aphyric basalt with plagioclase, Ti-augite, olivine and ore. In all three groups residual material forms typically five per cent of the rock.

In the lower lava formation olivine basaltic dykes predominate but tholeiitic dykes can also be found. The number of dykes is locally considerable: in a ravine on the south side of Nûlûp qáqai the dilatation is about ten per cent. In the lower member of the upper lava formation tholeiitic dykes predominate, but a few alkaline dykes are found. They are typically $2-5 \mathrm{~m}$ broad.

The dykes in the upper member are typically concentrated in belts in the major fault zones, whereas the areas between these fault zones are only cut by a few dykes. Many dykes are for instance found at Itsatagdlip qôrua about $5 \mathrm{~km}$ from the coast, at Naqerdloq about $7 \mathrm{~km}$ from the coast and west of Kugssininguaq at the south coast.

More than half of the dykes consist of tholeiitic basalt, whereas the rest are faintly alkaline. (Note that alkaline dykes are predominant on Hareøen, which is assumed to represent a high level in the upper member (Hald, 1971)). The two types of dykes have apparently the same areal distribution and are found both in the fault zones and in the areas between.

The dykes in the upper member are typically a little wider than those in the lower member, but are seldom wider than $5 \mathrm{~m}$. The dykes are as a whole parallel with the major faults, both in the lower lava formation and in the upper lava formation.

\section{Structure}

The olivine basalts near the Itivdle valley have strongly varying strikes and dips. At the north coast the lavas in the upper unit strike N-S and dip $0-30^{\circ} \mathrm{W}$ whereas in the rest of the area they strike NNE-SSW and dip 0-30 $\mathrm{WNW}$.

As pointed out by Münther (1973) and Henderson (in press) western Nûgssuaq is cut by numerous normal faults. The system of normal faults immediately north-west of the Itivdle valley has resulted in downthrow to the west and north-west with cutting out of parts of the lava sequence. Further to the northwest are faults which are antithetic to the main system and have resulted in downthrow to the east and south-east thus giving a repetition of parts of the upper lava formation, particularly noticeable east of Nûluk on the north coast, see section A-B in fig. 3. 
It is characteristic that the fault density is essentially greater in the lower member than in the upper member. As moreover an angular unconformity is found between the upper and the lower members, it seems likely that already after the formation of the lower member tilting took place towards the west along with the formation of normal faults. As a result of these movements a strong relief may have been created, with consequent erosion and deposition of the coarse-grained sediments. Hereafter the basalts of the upper member were erupted. Subsequently a renewed tilting of the layers towards the west has taken place accompanied by faulting.

\section{Thickness of the upper lava formation}

The total thickness of the upper lava formation cannot be estimated as the contact with the underlying basalts, as mentioned earlier, is faulted. The thickness of the part of the lower member that lies between Iterdlakavsak and the sediments west of Nûluk can be estimated to be $750 \mathrm{~m}$. The thickness of the coarse-grained sediments varies but is typically $150 \mathrm{~m}$ on the north coast of Nûgssuaq.

The thickness of the upper member can be estimated to be $2000 \mathrm{~m}$ under the assumption that the thin peralkaline tuffs lie at approximately the same level and that the faults west of the exposures of the composite lava have only small displacements. The total thickness of the upper lava formation on western Nûgssuaq west of Iterdlakavsak can accordingly be estimated to be $3 \mathrm{~km}$.

\section{References}

Hald, N. 1971: An investigation of the igneous rocks on Hareøen and western Nûgssuaq, West Greenland. Rapp. Grønlands geol. Unders. 35, 11-13.

Henderson, G. 1969: Field work supplementing photogeological interpretation of Nûgssuaq Rapp. Grønlands geol. Unders. 19, 18-21.

Henderson, G. (in press): The geological setting of the West Greenland basin in the Baffin Bay region. Pap. geol. Surv. Can. 71-23.

Koch, B. E. 1964: Review of fossil floras and nonmarine deposits of West Greenland. Bull. geol. Soc. Amer. 75, 535-548.

Munck, S. \& Noe-Nygaard, A. 1957: Age determination of the various stages of the Tertiary volcanism in the West Greenland basalt province. 20th int. geol. Congr., Mexico, 1956 1, 247-256.

Münther, V. 1973: Results from a geological reconnaissance around Svartenhuk Halvø, West Greenland. Rapp. Grønlands geol. Unders. 50, 26 pp.

Nordenskiöld, A. E. 1871: Redogörelse för en expedition till Grönland år 1870. Öfver VetenskAkad. Förh. 27, 10, 973-1082.

Pedersen, A. K. 1970: En petrologisk undersøgelse af tertiære vulkanske bjergarter fra det nordlige Disko. Unpublished prize dissertation. Univ. of Copenhagen. (Reviewed in Festskrift udgivet af Københavns Universitet $i$ anledning af Universitetets airsfest 1970, 379-383.

Steenstrup, K. J. V. 1883: Om Forekomsten af Forsteninger i de kulførende Dannelser i NordGrønland. Meddr Grønland 5, 43-77. 